\title{
Origin and colonization history of the white-clawed crayfish, Austropotamobius pallipes, in Ireland
}

\author{
N Gouin ${ }^{1}$, F Grandjean ${ }^{1}$, S Pain ${ }^{1}$, C Souty-Grosset ${ }^{1}$ and J Reynolds ${ }^{2}$ \\ ${ }^{1}$ Laboratoire de Génétique et Biologie des Populations de Crustacés, UMR CNRS 6556, Université de Poitiers, 40 Avenue du recteur \\ Pineau, F-86022 Poitiers cedex, France; ${ }^{2}$ Department of Zoology, University of Dublin-Trinity College, Dublin 2, Ireland
}

\begin{abstract}
The presence of the white-clawed crayfish Austropotamobius pallipes complex in Ireland is suspected to be a result of human translocations. Two hypotheses have been formulated about the origin of the crayfish: from British populations or from western French populations. In order to resolve this question, nine Irish crayfish populations (a total of 124 individuals) were sampled along a south-north cline and investigated by combining two molecular markers: mtDNA and RAPDs. The mtDNA marker, analysed by RFLP on the entire molecule, showed an absence of polymorphism within and among Irish populations. The RFLP haplotype found in
\end{abstract}

Irish populations was only recorded in western French populations and was different from those found in English populations. This result may be explained by a human introduction of crayfish to Ireland from western French populations. RAPD analysis showed a clinal reduction of genetic variability within Irish populations from south to north, associated with an increase in their genetic differentiation. A stepwise model of translocation from the south to the north of Ireland is proposed and discussed.

Heredity (2003) 91, 70-77. doi:10.1038/sj.hdy.6800282

Keywords: Austropotamobius pallipes; mtDNA; RAPD; translocation; founder event; genetic differentiation

\section{Introduction}

The white-clawed crayfish Austropotamobius pallipes (Lereboullet, 1858) is native to Western Europe including France, England, Ireland and North of Italy (Grandjean et al, 2000). This species has suffered from drastic declines in natural populations over the past century, attributable not only to water pollution and habitat destruction but also to the effects of competition and disease from introduced crayfish species, and is endangered or threatened in most of its range. In Ireland, $A$. pallipes is the sole crayfish species, still widespread throughout lowland areas (Reynolds, 1997). To date, most studies of Irish crayfish populations have focused on distribution, habitat characteristics, reproduction and growth (e.g., Lucey and McGarrigle, 1987; Reynolds, 1988; Matthews and Reynolds, 1995; O’Byrne et al, 1999). But little is known about their origin, a question that is still debated.

According to Coxon (2001), Ireland was entirely covered by ice at the glacial maximum, and no aquatic organism could have survived in Ireland or nearby. Since no records were found in the literature and archives of the presence of crayfish in Ireland from earlier than the 17th century, Lucey (1999) argued in favour of a recent origin of this species, probably through human introduction from Britain. On the other hand, Reynolds (1997) had suggested that $A$. pallipes might have been intro-

Correspondence: C Souty-Grosset, Laboratoire de Génétique et Biologie des Populations de Crustacés, UMR CNRS 6556, Université de Poitiers, 40 Avenue du recteur Pineau, F-86022 Poitiers cedex, France.

E-mail: catherine.souty@univ-poitiers.fr

Received 15 July 2002; accepted 4 February 2003 duced by monastic orders from France as early as the 12th century. During the Middle Ages, humans started to have a major impact on animal distribution, transporting and introducing many to other geographical areas (Laurent, 1988). Large-scale geographical translocations (human-mediated introductions) of white-clawed crayfish have already been reported in Europe. Based on a population genetics study, Souty-Grosset et al (1997) identified two French populations of $A$. pallipes that had been mixed with other forms: one with white-clawed crayfish originating from Slovenia ( $A$. italicus carsicus), the other with white-clawed crayfish from Spain ( $A$. italicus italicus). More recently, Grandjean et al (2001) also reported that the Spanish crayfish stock originated from Italian specimens of $A$. italicus italicus. In a preliminary study including two Irish populations and based on the analysis of the genetic polymorphism at RAPD loci, Gouin et al (2001) revealed that these Irish populations were significantly differentiated from populations sampled in France and England. Whereas the absence of genetic structure between French and British populations has been explained by postglacial colonization from France via stream connections (Grandjean et al, 1997), the genetic differentiation of Irish populations has been interpreted as the possible result of human translocations that could have led to Irish populations becoming genetically differentiated from those of England and France through founder effects. However, even if there is now strong evidence for the introduction of $A$. pallipes into Ireland, the question about the origin of translocated animals remains unresolved.

The analysis of mitochondrial DNA (mtDNA) could be very useful for this purpose. This molecule is circular, maternally inherited and nonrecombinant with a high 
rate of evolution compared to the nuclear genome: properties that make this marker a powerful tool for phylogenetic studies (Avise et al, 1987). In A. pallipes, a significant study has been carried out by RFLP analysis of mt DNA, including animals from 25 populations located in France and England (Grandjean and SoutyGrosset, 2000). These authors reported a high genetic variability within and among populations distributed in southern France. They also found a decrease of the genetic diversity within populations from the south to the north of France, attributed to the recolonization process following the ice retreat in the late Pleistocene. Thus, the great ability of mtDNA RFLP analysis to reveal polymorphism in $A$. pallipes makes this technique particularly appropriate to define the origin of Irish crayfish. Moreover, it could be useful to apply an additional more polymorphic genetic marker, such as nuclear markers, to elucidate the genetic structure among Irish populations. In crayfish, allozymes display a very low level of variation (Fetzner and Crandall, 2001), and would probably not be informative enough to analyse the colonization history within Ireland. The RAPD method (Williams et al, 1990) has been successfully used by Gouin et al (2001) to assess the distribution of the genetic variation throughout a large part of $A$. pallipes range. With six polymorphic markers, these authors found a pattern of genetic differentiation similar to that obtained from mt DNA analysis by Grandjean and Souty-Grosset (2000), showing that this method is able to give consistent data if employed with caution. Moreover, these nuclear markers should be able to reveal the gradual genetic decrease from more ancient Irish established populations to more recent ones, as a result of the colonization process (Nei et al, 1975; Hewitt, 1996).

\section{Materials and methods}

\section{Sampling}

In Ireland, A. pallipes is spread throughout lowlands wherever the water contains sufficient lime (Reynolds, 1997). Our strategy has consisted of sampling populations across the widest possible range of the species distribution in this country. In total, 124 specimens of $A$. pallipes were collected under license from nine Irish populations (Figure 1): Ballybooden (latitude: $52^{\circ} 83^{\prime} \mathrm{N}$; $n=11$ ), Fertagh (latitude: $52^{\circ} 85^{\prime} \mathrm{N} ; n=8$ ), Cloughjordan (latitude: $53^{\circ} 00^{\prime} \mathrm{N} ; n=16$ ), Blessington (latitude: $53^{\circ} 11^{\prime}$ $\mathrm{N} ; n=10$ ), Brittas (latitude: $53^{\circ} 15^{\prime} \mathrm{N} ; n=9$ ), Rath (latitude: $53^{\circ} 54^{\prime} \mathrm{N} ; n=13$ ), Glenade (latitude: $54^{\circ} 25^{\prime} \mathrm{N}$; $n=14$ ), Nageage (latitude: $54^{\circ} 53^{\prime} \mathrm{N} ; n=17$ ), Veenagreane (latitude: $54^{\circ} 53^{\prime} \mathrm{N} ; n=16$ ). After sampling, animals were kept alive, taken to the laboratory, and maintained in aquaria for subsequent analysis.

\section{mtDNA isolation and RFLP analysis}

The method described in Grandjean and Souty-Grosset (1996) was used to extract total mtDNA from samples (ovaries, testes and green gland). This method used an adapted extraction buffer with a high concentration of EDTA and a specific lysis of mitochondrial membranes by Nonidet P40. MtDNA samples were digested with seven restriction endonucleases, five four-base cutters (HaeIII, AccII, TaqI, NdeII and HpaII) and two six-base cutters (HindIII and EcoRI) according to the manufac- turer's instructions (Gibco BRL, Life Technologies). The resulting restriction fragments were separated in $1.5 \%$ agarose gels in Tris-EDTA buffer (30 and $60 \mathrm{mM})$ for $15 \mathrm{~h}$ at $30 \mathrm{~V}$. Gels were stained with $\mathrm{SYBR}^{\mathrm{TM}}$ Green I (FMC Bioproducts, Tebu, S.A.) and visualized with a UV light transilluminator.

Sizes of fragments were estimated by running phage lambda DNA digested with HindIII simultaneously on each agarose gel. Fragments less than 400 base pairs (bp) in length could not be scored. Distinct single restriction fragment patterns were identified by a specific letter in order of appearance. Thus, each crayfish was assigned a composite mtDNA genotype representing distinct combinations of polymorphic restriction sites observed across seven restriction enzymes.

\section{RAPD analysis}

Total genomic DNA was isolated from claw or abdominal muscle tissue. Tissue (approximately $2 \mathrm{~g}$ ) was ground with plastic pestles in microcentrifuge tubes that contained $100 \mathrm{mM}$ Tris, $10 \mathrm{mM}$ EDTA, $100 \mathrm{mM} \mathrm{NaCl}$, $0.1 \%$ SDS, $50 \mathrm{mM}$ DTT and $10 \mu \mathrm{g} / \mathrm{ml}$ proteinase $\mathrm{K}$ (Kocher et al, 1989). Samples were incubated at $37^{\circ} \mathrm{C}$ for $4 \mathrm{~h}$ and DNA was extracted twice with phenol/chloroform/isoamyl alcohol (25:24:1) followed by one additional chloroform wash. The DNA was then precipitated with 1 volume of isopropanol and 1/10 volume of $3 \mathrm{mM}$ $(\mathrm{pH}=5.2)$ sodium acetate. DNA was collected by centrifugation, dried and diluted in water to a final concentration of $20 \mathrm{ng} / \mu \mathrm{l}$.

PCR reactions were performed in a total volume of $25 \mu \mathrm{l}$ containing $2.5 \mu \mathrm{l}$ Taq polymerase buffer (Promega: $50 \mathrm{mM} \mathrm{KCl}, 10 \mathrm{mM}$ Tris- $\mathrm{HCl}, \mathrm{pH}=9.0,0.1 \%$ Triton X100), $2 \mathrm{mM} \mathrm{MgCl}_{2}, 100 \mu \mathrm{M}$ each dNTP, 5 pmol primer, $0.75 \mathrm{U} \mathrm{Taq}$ polymerase (Promega) and $20 \mathrm{ng}$ total DNA. The cycling programme was $2 \mathrm{~min}$ at $94^{\circ} \mathrm{C}, 1 \mathrm{~min}$ at $35^{\circ} \mathrm{C}$, $2 \mathrm{~min}$ at $72^{\circ} \mathrm{C}$ followed by $1 \mathrm{~min}$ at $94^{\circ} \mathrm{C}, 1 \mathrm{~min}$ at $35^{\circ} \mathrm{C}$, $2 \mathrm{~min}$ at $72^{\circ} \mathrm{C}$ for 44 cycles and a final extension of $5 \mathrm{~min}$ at $72^{\circ} \mathrm{C}$, using a Trio-Thermoblock (BIOMETRA GmBH, Göttingen, Germany). The search for polymorphism was performed from two sets (Kit A: OPA 1-20 and Kit C: OPC 1-20) of 10-mer primers, all purchased from Operon Technologies (Alameda, CA, USA). According to Gouin et al (2001), only three loci were polymorphic in the Irish populations of $A$. pallipes (Table 1). The search for polymorphism was therefore extended to primers that had not been previously tested. Five primers that revealed polymorphism were selected to give positive and reproducible results: OPC-04, OPA-01, OPA-02, OPA-10 and OPA-12 (Table 1). A negative control (without DNA template) was included with every amplification run to ensure that scorable fragments were not artefacts. Amplified products were separated in $1.5 \%$ agarose gels in $1 \times$ TAE $(40 \mathrm{mM}$ Tris base, $20 \mathrm{mM}$ acetic acid, $2 \mathrm{mM}$ EDTA, $\mathrm{pH}=8.4$ ), stained with ethidium bromide and visualized on a UV transilluminator $(254 \mathrm{~nm})$. The size of amplified fragments was estimated by comparison with a size standard (Marker MVI, Boerhinger Manheim, Germany). Bands were scored by placing the negatives of each photograph over a lightbox. By comparing fingerprints within and between gels, we could identify RAPD fragments that were always present with a particular primer and those that were polymorphic. Only bands of high intensity were taken into 


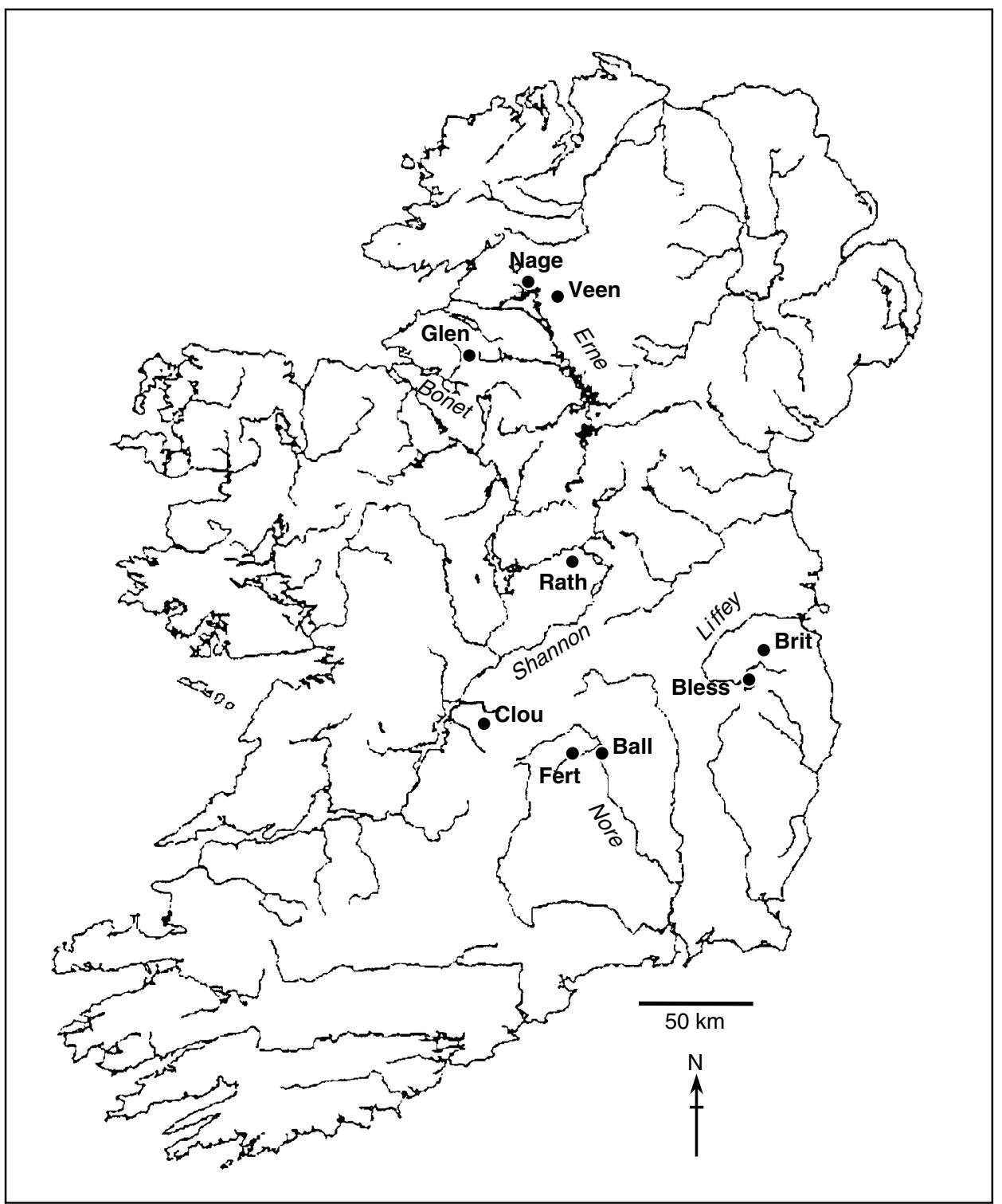

Figure 1 Locations of the nine Irish populations of A. pallipes included in this study. River basins are shown in italics, and codes for populations correspond to the first four letters of the population name.

Table 1 RAPD primers used in this study, their sequence, the name and the size of the scored polymorphic loci

\begin{tabular}{|c|c|c|c|}
\hline Primer & Sequence $\left(5^{\prime}>3^{\prime}\right)$ & Scored polymorphic loci & Size $(b p)$ \\
\hline OPC-04 & CCGCATCTAC & $C 04-1^{\mathrm{a}}$ & 627 \\
\hline OPA-01 & CAGGCCCTTC & A01-1 ${ }^{\mathrm{a}}$ & 1600 \\
\hline OPA-02 & TGCCGAGCTG & A02-1 & 1220 \\
\hline OPA-10 & GTGATCGCAG & A10-1 ${ }^{\mathrm{a}}$ & 795 \\
\hline \multirow[t]{4}{*}{ OPA-12 } & TCGGCGATAG & A12-1 & 809 \\
\hline & & A12-2 & 732 \\
\hline & & A12-3 & 525 \\
\hline & & A12-4 & 435 \\
\hline
\end{tabular}

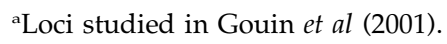

account because they are the most reproducible (Skroch and Nienhuis, 1995). RAPD markers were then scored if they displayed a clear polymorphism (ie, presence or absence) with no faint amplification. If there was a doubt about the reliability of a band, the reaction was repeated before scoring definitively.

\section{Data analysis}

RFLP mtDNA haplotypes were compared with those obtained by Grandjean and Souty-Grosset (2000).

The analysis of RAPD data was performed only with polymorphic amplification products. Each variable band was scored as present (1) or absent (0) and was considered to represent the phenotype of a distinct locus. Calculation of allele frequencies by compensating for deviation from Hardy-Weinberg equilibrium (Lynch and Milligan, 1994) was not attempted, except to test for linkage disequilibrium between loci. This test was performed to ensure that each locus was independent, particularly when several were generated by the same primer. With the assumption of Hardy-Weinberg equilibrium, each locus is considered di-allelic with a 
dominant allele (A) and a recessive (a). The presence of a band on the gel is expected to occur in homozygous (AA) or heterozygous individuals (Aa), and the absence of a band in homozygous individuals for the recessive allele (aa). Linkage disequilibrium was estimated with the program RAPDLD developed by Black (1997). Then, independence of loci was tested as described in Apostol et al (1996), by assuming that the expected frequency with which a pair of loci appears to be in disequilibrium will follow a binomial distribution.

Shannon's diversity index (Shannon and Weaver, 1949) was calculated to provide a relative estimate of the degree of genetic variation within each population using POPGENE 1.31 (Yeh, 1999). The extent of genetic differentiation among populations was quantified by computing pairwise $\Phi_{\mathrm{ST}}$, which are similar to estimates of $F_{\mathrm{ST}}$ (Excoffier et al, 1992), using ARLEQUIN version 2.0 (Schneider et al, 2000). The significance was obtained by 10000 permutations and adjusted for multiple simultaneous tests using the sequential Bonferroni correction (Rice, 1989), with an initial $\alpha$-value of $0.05 / k$ ( $k$ being the number of comparisons). The genetic distance between populations was estimated using the Reynolds' distance (Reynolds et al, 1983), computed with ARLEQUIN version 2.0. This $F_{\mathrm{ST}}$-based algorithm assumes that divergence between populations is only because of genetic drift and thus is a good estimator of the genetic distance for populations having recently diverged, as suspected in Ireland with the white-clawed crayfish. The relationships among populations were illustrated by a principal coordinate analysis (PCO) from pairwise Reynolds' distance values. Isolation by distance was tested by a Mantel test (Mantel, 1967) performed between pairwise $\Phi_{\mathrm{ST}}$ and geographic distance for all samples using GENETIX 3.3 (Belkhir et al, 1998). The significance was obtained by 1000 permutations.

The introduction of $A$. pallipes is most likely to have occurred through the ancient ports of southern or eastern Ireland. Because we could expect a decrease of the genetic variability from the initial founder populations during their subsequent spread, we estimated the correlation between the within population diversity (ie, Shannon's diversity values) and the populations' latitude using JMP software (version 3.2.2, SAS Institute Inc.).

\section{Results}

\section{mtDNA data}

From RFLP polymorphism of mtDNA, only one haplotype was found across all Irish stocks examined (ie, 124 animals in nine populations), revealing neither intra- nor interpopulation diversity. As described in Figure 2, it was compared with those obtained in other populations of A. pallipes by Grandjean and Souty-Grosset (2000). This haplotype corresponded to haplotype 2, restricted to a few populations located in western France.

\section{RAPD data}

The five random primers generated a total of eight unambiguous polymorphic loci, ranging in size from 435 to $1600 \mathrm{bp}$ (Table 1). The test for independence revealed no significant linkage disequilibrium between pairs of loci (data not shown); consequently each locus could be considered as independent.

A data matrix, detailing the presence/absence of each scored polymorphic RAPD band, is given in Table 2 . Across all the sampled Irish individuals, 57 RAPD

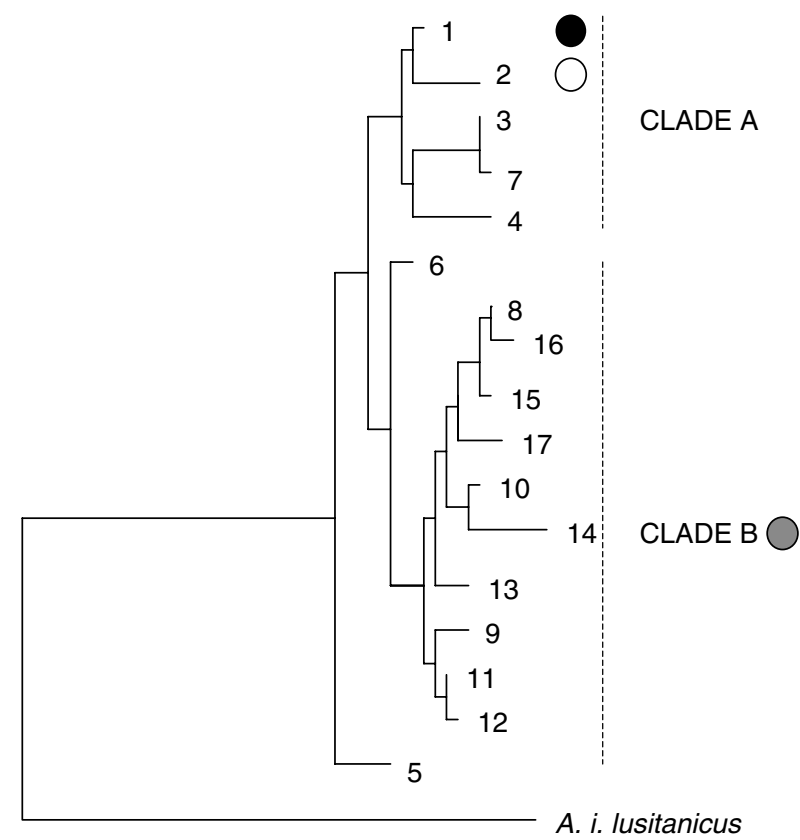

- $\quad 0.01 \%$ genetic distance

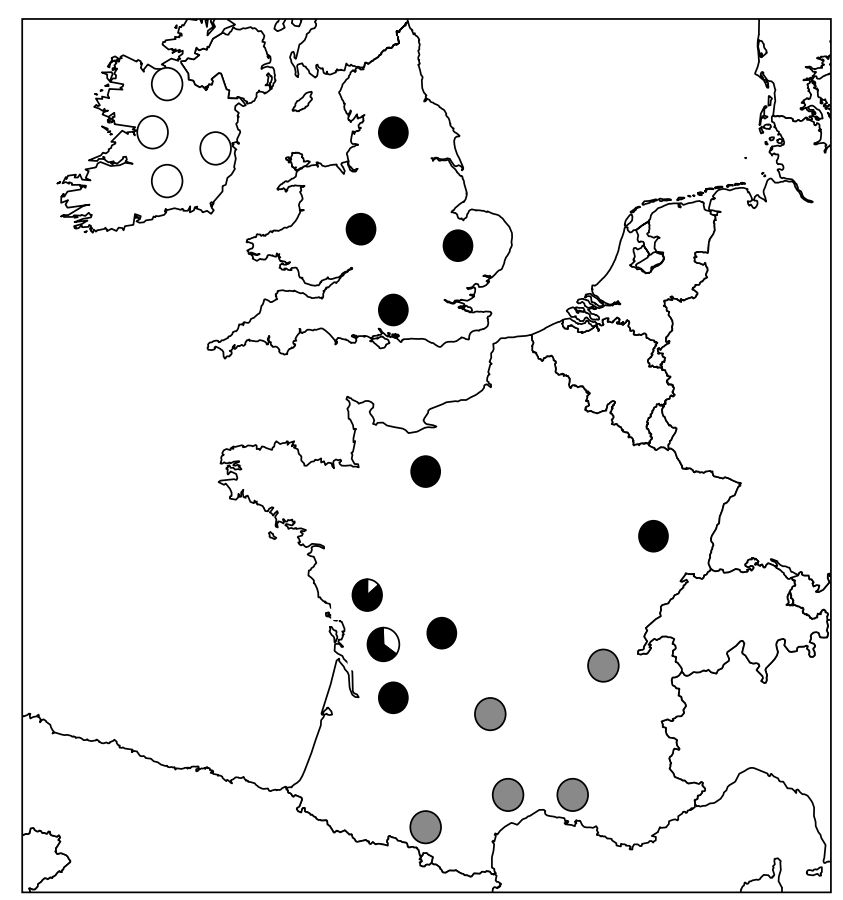

Figure 2 Comparison of the unique RFLP mtDNA haplotype found in Irish populations with the 17 RFLP haplotypes previously recorded in Western Europe by Grandjean and Souty-Grosset (2000). The neighbour-joining tree illustrating the relationships among the 17 RFLP haplotypes and the distribution of the two clades is adapted from Grandjean and Souty-Grosset (2000). Within clade A, only the distribution of haplotypes 1 and 2 is reported for the clarity of the manuscript. 
Table 2 Matrix obtained for the presence (1) or absence (0) of RAPD fragments in Irish samples of A. pallipes

\begin{tabular}{|c|c|c|c|c|c|}
\hline No. & RAPD phenotypes & Populations (n) & No. & RAPD phenotypes & Populations \\
\hline 1 & 10110000 & Bless (2), Ball (1), Rath (1), Fert (1) & 30 & 11110100 & Ball (1) \\
\hline 2 & 101110001 & Bless (2), Clou (1), Fert (1) & 31 & 001111010 & Rath (1) \\
\hline 3 & 100011010 & Bless (1) & 32 & 0001111101 & Rath (1), Glen (2) \\
\hline 4 & 00111000 & Bless (1), Rath (1) & 33 & 11111110 & Rath (1) \\
\hline 5 & $\begin{array}{llllllll}1 & 1 & 1 & 1 & 0 & 0 & 1 & 1\end{array}$ & Bless (1), Britt (1), Rath (1) & 34 & 011111000 & Rath (1) \\
\hline 6 & 100110011 & Bless (1), Clou (5) & 35 & 111111000 & Rath (1) \\
\hline 7 & 1111111101 & Bless (1) & 36 & 100011100 & Fert (1) \\
\hline 8 & 111110001 & Bless (1) & 37 & 10001000 & Fert (1) \\
\hline 9 & $\begin{array}{llllllll}0 & 0 & 1 & 1 & 0 & 0 & 0 & 1\end{array}$ & Britt (1), Rath (1), Glen (1) & 38 & 10111110 & Fert (1) \\
\hline 10 & 0111110011 & Britt (2), Rath (2) & 39 & 100110111 & Fert (1) \\
\hline 11 & 0001110011 & Britt (1), Glen (1) & 40 & 001110110 & Fert (1) \\
\hline 12 & 0111100101 & Britt (1) & 41 & 00011111111 & Glen (1) \\
\hline 13 & 011110101 & Britt (1), Glen (1) & 42 & 0101010101 & Glen (1) \\
\hline 14 & 11110000 & Britt (1), Ball (1) & 43 & 0000100011 & Glen (1) \\
\hline 15 & 10111101 & Britt (1) & 44 & $\begin{array}{llllllll}0 & 0 & 0 & 1 & 1 & 0 & 0 & 1\end{array}$ & Glen (1) \\
\hline 16 & 10110010 & Clou (3) & 45 & 011100001 & Glen (1) \\
\hline 17 & 10110100 & Clou (1) & 46 & $\begin{array}{lllllllll}0 & 1 & 1 & 0 & 0 & 1 & 0 & 1\end{array}$ & Glen (1) \\
\hline 18 & 1001111011 & Clou (1) & 47 & 0000000001 & Glen $(1)$ \\
\hline 19 & 1001111001 & Clou (1), Rath (1), Fert (1) & 48 & 0001010101 & Glen (1), Nage (3), Veen (4) \\
\hline 20 & 10111000 & Clou (1) & 49 & 000010001 & Nage (1) \\
\hline 21 & 10111010 & Clou (2) & 50 & 0001111011 & Nage (4), Veen (8) \\
\hline 22 & 1000100011 & Clou (1) & 51 & $\begin{array}{llllllll}0 & 0 & 1 & 0 & 0 & 0 & 0 & 1\end{array}$ & Nage (3) \\
\hline 23 & 1000100001 & Ball (1) & 52 & $\begin{array}{llllllll}0 & 0 & 1 & 0 & 0 & 0 & 1 & 1\end{array}$ & Nage (2) \\
\hline 24 & 11110010 & Ball (1) & 53 & 0001101111 & Nage (1) \\
\hline 25 & 11110101011 & Ball (1) & 54 & 00000101 & Nage (1) \\
\hline 26 & 11111010 & Ball (1) & 55 & $\begin{array}{lllllllll}0 & 0 & 0 & 0 & 1 & 0 & 0 & 1\end{array}$ & Nage (1), Veen (2) \\
\hline 27 & 00110000 & Ball (1), Rath (1), Glen (1) & 56 & 0010101101 & Nage (1), Veen (1) \\
\hline 28 & 10111100 & Ball (1) & 57 & $\begin{array}{lllllllll}0 & 0 & 1 & 1 & 1 & 0 & 0 & 1\end{array}$ & Veen (1) \\
\hline 29 & 11110110 & Ball (2) & & & \\
\hline
\end{tabular}

In parentheses: frequency of each RAPD phenotype per population (code for populations: as described in Figure 1).

Table 3 Genetic diversity estimates within Irish A. pallipes populations using the Shannon diversity index

\begin{tabular}{|c|c|c|c|c|c|c|c|c|c|}
\hline Population & $\mathrm{C} 04-1^{a}$ & $A 01-1^{a}$ & A02-1 & $A 10-1^{a}$ & A12-1 & A12-2 & A12-3 & A12-4 & $\mathrm{H}_{0}$ \\
\hline Ball & 0.601 & 0.681 & 0.373 & 0.601 & 0.509 & 0.453 & 0.521 & 0.579 & 0.550 \\
\hline Fert & 0.688 & 0.000 & 0.567 & 0.688 & 0.624 & 0.534 & 0.605 & 0.567 & 0.534 \\
\hline Clou & 0.000 & 0.134 & 0.640 & 0.554 & 0.554 & 0.494 & 0.134 & 0.693 & 0.400 \\
\hline Bles & 0.624 & 0.445 & 0.657 & 0.624 & 0.000 & 0.445 & 0.202 & 0.445 & 0.430 \\
\hline Brit & 0.445 & 0.681 & 0.636 & 0.000 & 0.000 & 0.202 & 0.337 & 0.534 & 0.354 \\
\hline Rath & 0.521 & 0.579 & 0.579 & 0.000 & 0.000 & 0.627 & 0.279 & 0.521 & 0.388 \\
\hline Glen & 0.000 & 0.411 & 0.580 & 0.693 & 0.693 & 0.477 & 0.534 & 0.411 & 0.475 \\
\hline Veen & 0.000 & 0.000 & 0.000 & 0.650 & 0.141 & 0.000 & 0.141 & 0.394 & 0.166 \\
\hline Nage & 0.000 & 0.000 & 0.000 & 0.680 & 0.229 & 0.675 & 0.229 & 0.586 & 0.299 \\
\hline
\end{tabular}

aLoci studied in Gouin et al (2001) (code for populations: as described in Figure 1).

phenotypes were revealed by the eight primers showing extensive variation in RAPD banding patterns, even between individuals originating from the same location. Each population harboured a high number of specific RAPD phenotypes. However, many haplotypes were shared among southern populations. Intrapopulational genetic diversity was illustrated by Shannon diversity estimates whose mean $\left(H_{0}\right)$ ranged from 0.166 in Veenagreane to 0.550 in Ballybooden (Table 3). Most of the populations displayed a level higher than 0.354, except for Nageage and Veenagreane, from the Erne catchment, which exhibit the lowest intrapopulational genetic diversity (respectively 0.299 and 0.166). According to Figure 3, the genetic diversity within Irish populations was correlated $\left(r^{2}=0.477 ; P=0.039\right)$ with their latitudinal distribution, illustrating a decreasing cline of genetic variation from the south of Ireland to the north. However the point a, corresponding to the Glenade population, diverged from the regression line which could have reduced the correlation between these two variables. According to Table 4, most of the Irish populations appeared genetically differentiated. The overall $\Phi_{\mathrm{ST}}$ value was estimated at 0.319 between populations. The PCO based on Reynolds' distances (Figure 4) appeared highly informative because most of the genetic structure information was expressed on the first two axes: $67.8 \%$ for axis 1 and $22 \%$ for axis 2 . The first axis clearly differentiated a group composed of southern populations (Brit, Rath, Ball, Bles, Fert and Clou) from that in Glenade, itself well separated from the northern populations Nageage and Veenagreane. Although less informative, the second axis revealed that the Glenade population was closer to Brittas and Rath than to Nageage and Veenagreane, probably because 


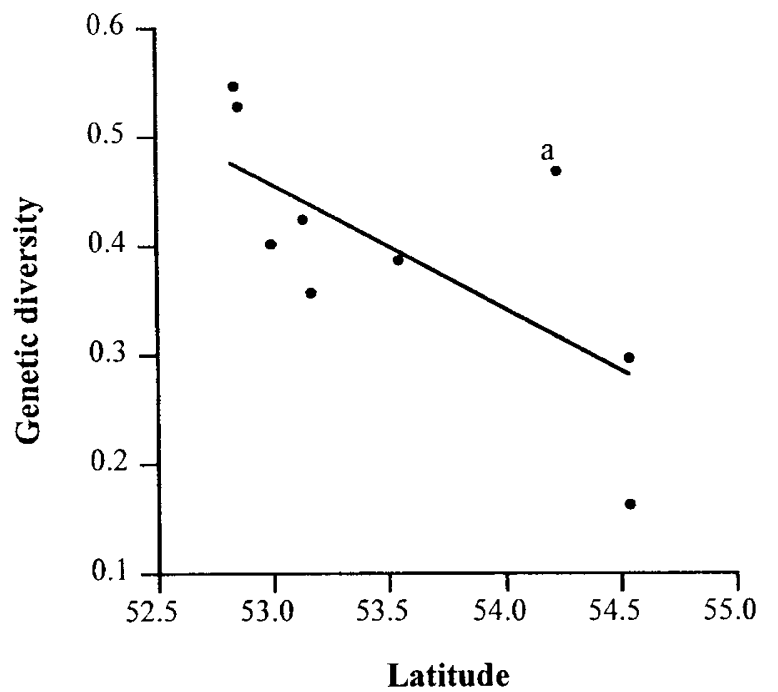

Figure 3 Regression line for Shannon's diversity estimates versus corresponding latitudes $\left(y=6.578 x-0.115 ; r^{2}=0.47697\right)$.

they shared more RAPD phenotypes (see Table 2). The Mantel test performed on all Irish populations showed a pattern of isolation by distance $(r=0.720 ; P<0.001)$.

\section{Discussion}

Origin of crayfish in Ireland

In a recent study of RFLP mtDNA variation within $A$. pallipes, including 25 populations sampled in France and England, Grandjean and Souty-Grosset (2000) found 17 haplotypes distributed in two geographically separated clades A and B. Clade A included animals sampled in northern and western parts of France and England, whereas Clade B included individuals sampled in southern and eastern parts of France. The haplotype found in Irish populations was included in cluster A. Within A, Grandjean and Souty-Grosset (2000) found five haplotypes, one being widespread in both northern French and English populations and the other four restricted to a few populations located in the western part of France. According to their data, the haplotype that occurs in Irish populations is one of the four rare haplotypes only recorded in a few populations situated in the Charentes and Sèvre Niortaise catchment. This

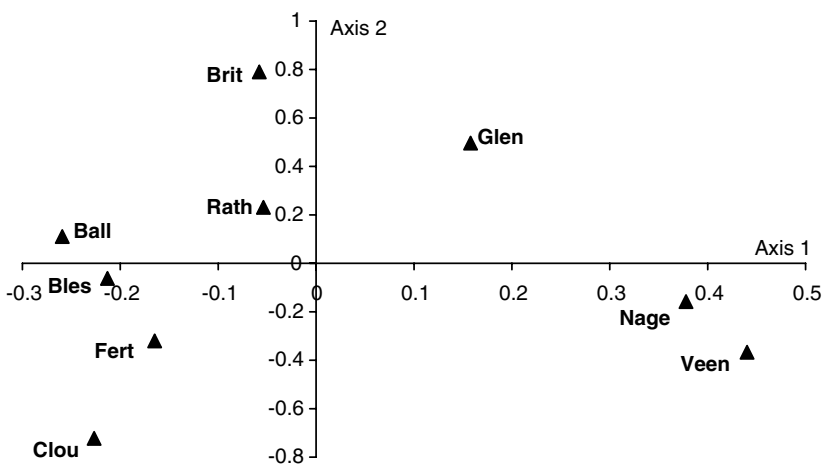

Figure 4 Principal coordinate analysis based on Reynolds' distance values obtained between Irish populations.

result supports the hypothesis of introduction of crayfish from populations located in western France, and clearly rejects the transfer of crayfish from England to Ireland suspected by Lucey (1999). However, it supports the hypothesis proposed by Reynolds (1997), who suggested that crayfish may have been introduced to Ireland by French continental religions during the Middle Ages.

As a consequence of translocations, a depletion of genetic diversity should be observed in introduced populations through bottleneck events (Leberg, 1992; Hartl and Pucek, 1994). In Irish populations no genetic variation of mtDNA was observed within and among populations because only one haplotype was found in 124 animals. These results are in accordance with the theoretical genetic consequence of translocation from a limited number of individuals, and are similar to those shown from other recently established populations of $A$. italicus in Spain (Grandjean et al, 2001). In their study, Grandjean et al (2001) found one haplotype in 154 animals sampled from 14 Spanish populations. The loss of genetic variation could be extremely rapid throughout the genome in small or localized populations founded by a few individuals and cut off from gene exchange with the main body of the species (Planes and Lecaillon, 1998). In a review of studies of introduced birds, Merilä et al (1996) noted that reductions in genetic diversity tended to be inversely correlated with the number of individuals released. Thus, according to our results, it seems likely that Irish white-clawed crayfish are derived from a low number of introduced individuals translocated from populations in western France.

Table 4 Pairwise $\Phi_{\mathrm{ST}}$ values (below the diagonal) and Reynolds' distance values (above the diagonal)

\begin{tabular}{|c|c|c|c|c|c|c|c|c|c|}
\hline & Ball & Fert & Clou & Bles & Brit & Rath & Glen & Veen & Nage \\
\hline Ball & & 0.072 & 0.242 & 0.047 & 0.211 & 0.091 & 0.391 & 0.852 & 0.704 \\
\hline Fert & 0.070 & & 0.120 & 0.025 & 0.308 & 0.112 & 0.267 & 0.639 & 0.508 \\
\hline Clou & $0.215^{*}$ & $0.113^{*}$ & & 0.072 & 0.421 & 0.256 & 0.527 & 0.794 & 0.672 \\
\hline Bles & 0.046 & $0.024^{*}$ & 0.069 & & 0.136 & 0.051 & 0.284 & 0.707 & 0.564 \\
\hline Brit & $0.191^{*}$ & $0.265^{*}$ & $0.344^{*}$ & $0.127^{*}$ & & 0.058 & 0.105 & 0.654 & 0.471 \\
\hline Rath & $0.087^{*}$ & $0.106^{*}$ & $0.226^{*}$ & 0.049 & 0.057 & & 0.147 & 0.427 & 0.383 \\
\hline Glen & $0.323^{*}$ & $0.235^{*}$ & $0.409^{*}$ & $0.247^{*}$ & $0.099^{*}$ & $0.136^{*}$ & & 0.317 & 0.166 \\
\hline Veen & $0.574^{*}$ & $0.472 *$ & $0.548^{*}$ & $0.507^{*}$ & $0.480^{*}$ & $0.348^{*}$ & $0.271^{*}$ & & 0.068 \\
\hline Nage & $0.506^{*}$ & $0.398^{*}$ & $0.489^{*}$ & $0.431^{*}$ & $0.376^{*}$ & $0.318^{*}$ & $0.153^{*}$ & 0.066 & \\
\hline
\end{tabular}

${ }^{*} P<0.05$; bold characters: significant pairwise comparisons after Bonferroni sequential correction (the initial $\alpha$ level for 36 comparisons is 0.0014); code for populations: as described in Figure 1. 
Colonization history within Ireland

The RAPD method allowed us to reveal a substantial amount of genetic variability in Irish populations of $A$. pallipes. With eight polymorphic loci, 57 RAPD phenotypes could be differentiated in 124 animals. This level of genetic polymorphism from RAPD may appear high compared with the lack of differentiation seen through mtDNA. As described by Villablanca et al (1998) in the Mediterranean fruit fly, the reduction in diversity associated with colonization bottlenecks is exacerbated for mitochondrial genes because they have only a quarter of the effective population size of nuclear genes. RAPD markers might also be able to retain a large part of the ancestral polymorphism. In a comparison between RAPDs and allozymes in the medfly, Baruffi et al (1995) revealed that invading populations showed a five-fold decrease in allozyme variation compared with ancestral populations, whereas RAPDs showed only a two-fold decrease. However, if we consider that only eight polymorphic markers were scored in A. pallipes from a set of 40 primers, this level appears very low compared to the RAPD variability already described for other animals in general (eg, Mamuris et al, 1999; Cooper, 2000).

A clinal reduction in genetic variability within populations was observed from the south to the north of Ireland. To explain this result, two hypotheses may be postulated. First, differences in population size are known to influence the degree of genetic variation within populations (Wright, 1978; Lande, 1995). Because Ireland lies at the northern distributional limit of $A$. pallipes, we may assume a tendency for population size reduction from south to north because of climatic influences on ecosystems. However, oceanity leads to low climatic variation across Ireland. Mean annual temperatures are $10-11^{\circ} \mathrm{C}$ throughout, with mean January temperatures between 4 and $5^{\circ} \mathrm{C}$, and means for July between 15 and $16^{\circ} \mathrm{C}$ (Royal Irish Academy 1979, Atlas of Ireland; Meteorological data). Furthermore, population size, estimated by hand-catching rates, indicates substantial populations at the northern sites such as Glenade or Veenagreane comparable to those further south (J. Reynolds, unpublished data), making this hypothesis unlikely. In fact, the reduction in genetic variation within populations from south to north seems more likely to be the result of the colonization history of A. pallipes through Ireland. As described by Hewitt (1996) for postglacial colonization, successive bottlenecks during a colonization process lead to the loss of genetic diversity in newly founded populations. Since populations belonging to the Nore drainage displayed the greatest intrapopulational variability and are close to the southern limit of $A$. pallipes distribution in Ireland (Holdich and Rogers, 1997; Reynolds, 1998), we may suggest that the first populations of white-clawed crayfish were founded in the south of this country and that colonization occurred from the south to the north.

According to the observed pattern of isolation by distance, the more geographically close, the less genetically differentiated the populations. As they are isolated in different drainages, the pattern of isolation by distance could be explained by step-by-step translocation events. This idea is also supported by the decrease in variation with latitude. As recently described by Williams et al (2002), translocations can have an important impact on populations genetic variability. Indeed, they showed in the elk Cervus elaphus that a reintroduced herd had experienced a $61.5 \%$ decrease in heterozygosity relative to its source herd. In $A$. pallipes, we may then assume that the decrease in variation with latitude could be the result of successive translocations following a stepwise model from an initial introduced population in the south of Ireland, each higher-latitude population being a subsample of the previous. This process would have favoured the genetic differentiation of white-clawed crayfish populations in Ireland by increasing the genetic drift effects. Such a phenomenon was observed in the rare endemic frogs of the genus Geocrinia in Australia by Driscoll et al (1994): they observed very high levels of genetic subdivision over short distances, related to possible translocations of these species for their conservation.

In summary, the successive translocation events from an initial introduced population of $A$. pallipes in the south of Ireland would have entailed a succession of founder effects responsible for the clinal distribution of genetic diversity from the south to the north. The colonization history may have happened step by step among geographically close locations, triggering a progressive genetic differentiation of populations along this axis under genetic drift effects. Therefore, these results point out the strong impact of past uncontrolled translocation events on genetic structuring in natural populations.

\section{Acknowledgements}

Special thanks are due to M Raimond and C Debenest for technical assistance. We are grateful to $\mathrm{F}$ Marnell (Duchas-Irish National Parks and Wildlife), D Cotton (Institute of Technology, Sligo) and M Matthews (Northern Regional Fisheries Board, Ballyshannon) for assistance with collecting the crayfish samples. This work was supported by a doctoral fellowship from the Région Poitou-Charentes and by a travel grant from CNRS/ M.A.E./Enterprise Ireland, and was funded by the Conseil Supérieur de la Pêche (C.S.P.).

\section{References}

Apostol BL, Black WC, Reiter P, Miller BR (1996). Population genetics with RAPD-PCR markers: the breeding structure of Aedes aegypti in Puerto Rico. Heredity 76: 325-334.

Avise JC, Arnold J, Ball RM, Bermingham E, Lamb T, Neigel JE et al. (1987). Intraspecific phylogeography: the mitochondrial DNA bridge between population genetics and systematics. Ann Rev Ecol Systematics 18: 489-522.

Baruffi L, Damiani G, Guglielmino R (1995). Polymorphism within and between populations of Ceratitis capitata: comparison between RAPD and multilocus enzyme electrophoresis data. Heredity 74: 425-437.

Belkhir K, Borsa P, Goudet J, Chikhi L, Bonhomme F (1998). GENETIX, logiciel sous Windows TM pour la génétique des populations.Version 3.3. Laboratoire Génome et Populations, CNRS UPR 9060, Université de Montpellier II, Montpellier, France.

Black WC (1997). FORTRAN programs for the analysis of RAPD-PCR markers in populations. Colorado State University, Ft Collins.

Cooper ML (2000). Random amplified polymorphic DNA analysis of southern brown bandicoot (Isodon obesulus) populations in western Australia reveals genetic differentiation to environmental variable. Mol Ecol 9: 469-479. 
Coxon P (2001). Cenozoic: tertiary and quaternary (until 10,000 years before present), Chapter 16. In: Holland $\mathrm{CH}$ (ed) The geology of Ireland, Dunedin Academic Press: Edinburgh. pp 387-428.

Driscoll D, Wardell-Johnson G, Roberts JD (1994). Genetic structuring and distribution patterns in rare southwestern Australia frogs: implications for translocation programs. In: Serena M (ed), Reintroduction Biology of Australia and New Zealand Fauna, Chipping Norton, Surrey Beatty and Sons. pp 85-90.

Excoffier L, Smouse PE, Quattro JM (1992). Analysis of molecular variance inferred from metric distances among DNA haplotypes; application to human mitochondrial DNA restriction data. Genetics 131: 479-491.

Fetzner JW, Crandall KA (2001). Genetic variation, Chapter 10. In: Holdich DM (ed) Biology of Freshwater Crayfish, Blackwell Science: Oxford, pp. 291-326. ISBN 0-632-05431-X.

Gouin N, Grandjean F, Bouchon D, Reynolds JD, Souty-Grosset C (2001). Genetic structure of the endangered freshwater crayfish Austropotamobius pallipes assessed using RAPD markers. Heredity 87: 80-87.

Grandjean F, Souty-Grosset C (1996). Isolation and characterization of mitochondrial DNA from the endangered whiteclawed crayfish Austropotamobius pallipes pallipes, Lereboullet, 1858. Bull Français la de Pêche Pisciculture 343: 175-180.

Grandjean F, Souty-Grosset C (2000). Mitochondrial DNA variation and population genetic structure of the whiteclawed crayfish, Austropotamobius pallipes pallipes. Conserv Genet 1: 309-319.

Grandjean F, Gouin N, Souty-Grosset C, Dieguez-Uribeondo J (2001). Drastic bottlenecks in the endangered crayfish species, Austropotamobius pallipes in Spain and implications for its colonization history. Heredity 86: 431-438.

Grandjean F, Harris DJ, Souty-Grosset C, Crandall KA (2000). Systematics of the European endangered crayfish species Austropotamobius pallipes (Decapoda: Astacidae). I Crustacean Biol 20(3): 522-529.

Grandjean F, Souty-Grosset C, Raimond R, Holdich DM (1997). Geographical variation of mitochondrial DNA between populations of the white-clawed crayfish Austropotamobius pallipes. Freshwater Biol 37: 493-501.

Hartl GB, Pucek Z (1994). Genetic depletion in the European bison (Bison bonasus) and the significance of electrophoretic heterozygosity for conservation. Conserv Biol 8: 167-194.

Hewitt GM (1996). Some genetic consequences of ice ages, and their role in divergence and speciation. Biol J Linnean Soc 58: 247-276

Holdich DM, Rogers WD (1997). The white-clawed crayfish, Austropotamobius pallipes, in Great Britain and Ireland with particular reference to its conservation in Great Britain. Bull Français Pêche Pisciculture, 347: 597-616.

Kocher TD, Thomas WK, Meyer A, Edwards SV, Pääbo S, Villablanca FX, Wilson AC (1989). Dynamics of mitochondrial DNA evolution in animals: amplification and sequencing with conserved primers. Proc Nat Acad Sci USA 86: 61962000.

Lande R (1995). Mutation and conservation. Conserv Biol 9: 782791.

Laurent PJ (1988). Austropotamobius pallipes and Austropotamobius torrentium, with observations on their interactions with other species in Europe. In: Holdich D, Lowery R (eds) Freshwater Crayfish Biology, Management and Exploitation, Chapman \& Hall: London. pp 341-364.

Leberg PL (1992). Effects of population bottlenecks on genetic diversity as measured by allozymes electrophoresis. Evolution 46: 477-494.

Lucey J, Mcgarrigle ML (1987). The distribution of the freshwater crayfish in Ireland. Irish Fisheries Invest 29A: 1-13.
Lucey J (1999). A chronological account of the crayfish Austropotamobius pallipes (Lereboullet) in Ireland. Bull Irish Biogeogeographical Soc 23: 143-161.

Lynch M, Milligan BG (1994). Analysis of population genetic structure with RAPD markers. Mol Ecol 3: 91-99.

Mamuris Z, Stamatis C, Triantaphyllis C (1999). Intraspecific genetic variation of striped red mullet (Mullus surmuletus $\mathrm{L}$.) in the Mediterranean sea assessed by allozyme and random amplified polymorphic DNA (RAPD) analysis. Heredity 83 30-38.

Mantel N (1967). The detection of disease clustering and a generalised regression approach. Cancer Res 27: 209-220.

Matthews MA, Reynolds JD (1995). A population study of the white-clawed crayfish Austropotamobius pallipes (Lereboullet) in an Irish reservoir. Biol Environ 95B: 99-109.

Merilä J, Björklund M, Baker AJ (1996). The successful founder: genetics of introduced Carduelis chloris (greenfinch) populations in New Zealand. Heredity 77: 410-422.

Nei M, Maruyama T, Chakraborty R (1975). The bottleneck effect and genetic variability in populations. Evolution 29: 110.

O’Byrne CF, Lynch JM, Bracken JJ (1999). A sampling strategy for stream populations of white-clawed crayfish, Austropotamobius paloipes (Lereboullet) (Crustacea, Astacidae). Biol Environ 99B: 89-94.

Planes S, Lecaillon G (1998). Consequences of the founder effect in the genetic structure of introduced island coral reef fish populations. Biol J Linnean Soc 63: 537-552.

Reynolds JD (1988). Crayfish extinctions and crayfish plague in Ireland. Biol Conserv 45: 279-285.

Reynolds JD (1997). The present status of freshwater crayfish in Ireland. Bull Français Pêche Pisciculture 347: 693-700.

Reynolds JD (1998). Ireland's Freshwaters. Marine Institute: Dublin.

Reynolds J, Weir BS, Cockerham CC (1983). Estimation for the coancestry coefficient: basis for a short-term genetic distance. Genetics 105: 767-779.

Rice WR (1989). Analysing tables of statistical tests. Evolution 43 : 223-225.

Schneider S, Roessli D, Excoffier L (2000). Arlequin version 2000: a software for population genetics data analysis. Genetics and Biometry laboratory. University of Genova, Switzerland. http://anthropologie.unige.ch/arlequin.

Shannon CE, Weaver W (1949). The Mathematical Theory of Communication. University of Illinois Press: Urbana.

Skroch P, Nienhuis J (1995). Impact of scoring error and reproducibility of RAPD data on RAPD based estimates of genetic distance. Theor Appl Genet 91: 1086-1092.

Souty-Grosset C, Grandjean F, Raimond R, Frelon M, Debenest C, Bramard M (1997). Conservation genetics of the whiteclawed crayfish Austropotamobius pallipes: the usefulness of the mitochondrial DNA marker. Bull Francais Pêche Pisciculture 347: 677-692.

Villablanca FX, Roderick GK, Palumbi SR (1998). Invasion genetics in the Mediterranean fruit fly: variation in multiple nuclear introns. Mol Ecol 7: 547-560.

Williams CL, Serfass TL, Cogan R, Rhodes Jr OE (2002). Microsatellite variation in the reintroduced Pennsylvania elk herd. Mol Ecol 11: 1299-1310.

Williams JGK, Kubelik AR, Livak KJ, Rafalski JA, Tingey SV (1990). DNA polymorphisms amplified by arbitrary primers are useful as genetic markers. Nucleic Acids Res 18: 6531-6535.

Wright S (1978). Evolution and Genetics of Populations. Vol. IV: Variability Within and Among Populations. University of Chicago Press: Chicago, IL.

Yeh FC. (1999). POPGENE, version 1.31. Distributed by the author. http:/ / www.ualberta.ca/ fyeh/fyeh. 